\title{
On Improving the Process of Forming the Physical Readiness of Future Managers
}

\author{
Altynova N.V. \\ Faculty of Biotechnology and Agronomy \\ Chuvash State Agricultural Academy \\ Cheboksary, Russia \\ naltynova_777@mail.ru
}

\author{
Talantseva V.K. \\ Department of Physical Education \\ Chuvash State Agricultural Academy \\ Cheboksary, Russia \\ sport_chieim21@mail.ru
}

\begin{abstract}
The article discusses the question of improving the process of future managers physical education for the formation of their physical readiness proper level to carry out professional activities in the future. According to the authors, one of the effective means for the effective training of managerial personnel in higher education can be the use of a "physiological portrait" in the educational process in physical education. It consists of three blocks: physical development, functionality and physical fitness of students, which generally allows you to evaluate the physical health and level of students physical readiness. The authors experimentally (September 2016 - December 2018) proved the effectiveness of using the "physiological portrait" in the process of students physical education in the training direction 38.03.02 Management, which was confirmed by the positive dynamics of its indicators and testified to an increase in the level of students physical readiness for their upcoming professional activities. This was explained by the fact that regular monitoring of the "physiological portrait" indicators made it possible to make timely adjustments to the training of future managers and to build an individual trajectory of professional development with each of them. The experiment allows us to conclude that this development, taking into account professional profiling of the physical education process, leads to high-quality training a higher school graduate.
\end{abstract}

Keywords—students; physical education; physical readiness; professional training; managerial personnel.

\section{INTRODUCTION}

Management for modern Russia, in the period of the market economy, is of great importance [19, 20]. At present, information opportunities are expanding, the role of knowledge is increasing and the problem of managing them arises, the staff becomes human capital, the number of alternatives to solved problems in the processes is increasing. It turns management into science and at the same time it remains a unique art of working with people, which imposes new professional requirements on managers $[3,10]$.

Today, without the professionalization of management, without the training of professional managers, it is impossible to solve the most difficult problems in a globalized economy. The system of highly qualified personnel training acquires strategic importance, becomes the main tool for ensuring the high competitiveness of the national economy, and the issues of training competent, highly qualified specialists are becoming increasingly important.

The existing system of vocational training in higher education does not ensure the proper readiness of graduates for practical activities [9]. Therefore, in higher education, special attention in the training of future managers should be paid to the formation of readiness for future professional activity, during the entire period of training [4].

It is indisputable that the full use of professional knowledge and skills formed during the years of training is possible only with a good state of health, a high degree of graduates efficiency, their physical readiness for professional activity [23]. Therefore, today, the health of a young specialist becomes not only personal but also socioeconomic importance [17].

Taking into account the importance of future specialists physical readiness formation for professional activity during training at the University, in the theory of vocational education, numerous studies were conducted to determine the content, means, and methods of physical education in the training of various specialties representatives [16]. However, a review of theoretical literature and analysis of scientific research indicate insufficient illumination of future managers physical readiness proper level formation problem in the University $[1,5,11,22]$.

Today, based on the structure of the individual labor readiness system for professional activity, the term "physical readiness" refers to a specific physical condition of a person, ensuring the successful performance of any activity and characterized by appropriate physical development, a certain functional state of the body and the necessary level of motor readiness [7]. Therefore, the definition of physical readiness, refers to all three of its components: bodily (morphological), functional and motor [15].

Numerous studies of scientists and data of the Russia Security Council indicate that the current state of health and the level of students' physical fitness have a steady tendency 
to deterioration $[8,13,21]$, which is confirmed by our previous study to identify the level of the Economics faculty of senior students physical readiness. We stated the fact that today future graduates have an insufficient degree of its formation [6]. This is due to their poor health, the traditional approach to physical education and the existing formulation of the educational process. In this regard, we attempted to find ways to form students with an adequate level of physical readiness for their upcoming professional activities. In the course of the formative experiment conducted on the basis of FSBEI HE Chuvash State Agricultural Academy with the participation of students of the training direction 38.03.01 Economics in 2015 we proved the effectiveness of using special course of "Physical culture in the professional activity of a specialist" in the educational process of students' physical education" and creating certain pedagogical conditions for physical readiness of future graduates to the chosen profession [18].

In education, as one of the most important components of the holistic pedagogical process, a systematic review of the pedagogical effects on the consciousness, feelings, and will of students is required, in order to form them the necessary complex of human qualities. This directly applies to the process of students' physical education at the University, aimed at the constant search for the most effective forms, means and methods for the formation of future graduates physical readiness necessary level for future professional activities.

In this regard, the goal of our work was further search for ways to improve the process of physical education for the formation of the necessary level of physical readiness for upcoming professional activities of future managers.

\section{RESEARCH Methodology}

The study was conducted on the base of the Chuvash State Agricultural Academy (Cheboksary, Russia) in the period from September 2016 to December 2018 with the involvement of 100 students of the Economics Faculty, enrolled in the direction of training 38.03.02 Management, and classified by health for physical education classes to the main medical group. Voluntary participation in the study was confirmed by the students in informed written consent.

For effective control and formation of future graduates physical readiness for their upcoming professional activity, we suggested, along with the use in the educational process of students physical education in special course "Physical culture in the professional activity of a specialist", to additionally introduce "Physiological portrait" (PP) for the entire period students of physical education in high school. blocks:

Physiological portrait (PP) consisted of the following

- physical development indicators: the length of the body (standing and sitting), $\mathrm{cm}$; body mass, $\mathrm{kg}$, chest circumference (CC) - breath in, breath out, pause, tour, $\mathrm{cm}$; strength (wrist and deadlift), $\mathrm{kg}$;

- functional parameters of the cardiorespiratory system heart rate (HR), beats/min; systolic blood pressure (SBP), mmHg. St; diastolic blood pressure (dad), mm
Hg. St; pulse pressure (PD), mm Hg. article; vital capacity (VC), ml; samples of the Shtenge and Genchi;

- level of physical fitness (testing of physical abilities using control standards).

Assessment of students' physical development was carried out on anthropometric indicators: body length was measured using the stadiometer medical the RM-1P, body weight - medical floor scales RP-150 MG, muscle strength of hands using the dynamometer DRP-90, the strength of the back muscles using the dynamometer.

The monitoring functionality of the body basic physiological systems students made measurements of the chest circumference on the breath, exhale and at rest using a measuring tape. Chest excursion was calculated by the formula $\mathrm{EX}=\mathrm{OGKbi}-\mathrm{OGKbo}, \mathrm{cm}$ To assess the vital capacity of the lungs, a SP-01 spirometer was used. According to generally accepted methods Shtange and Genchi students were tested. Evaluation of the cardiovascular system function was established by heart rate, as well as blood pressure indicators: systolic, diastolic, and pulse. It was defined as the systolic blood pressurediastolic blood pressure difference.

The level of students' physical fitness revealed the following tests: running $100 \mathrm{~m}$, s; jump in length with a push of two legs, cm; power: flexion, extension of arms in the emphasis lying, number of times; running on $2000 \mathrm{~m}$, min.; tilt forward from standing position with straight legs on the gymnastic bench, $\mathrm{cm}$.

The experiment provided for monitoring the performance of AF throughout the period of study by students of the disciplines "Physical culture and sport" and "Physical culture and sport (elective discipline)."

To assess the parameters of physical development, functional indicators of the cardiorespiratory system and the level of physical fitness, the generally accepted methods of medical and pedagogical control were used. According to the results of the survey, a personalized database was created, statistical processing was carried out using the programs of the office package "Excel v8.00." To perform the tasks of the study, the methods of variation statistics, the method of assessing the reliability of the results (t-student's criterion, criterion $\chi^{2}$ ) with a confidence interval $\mathrm{P} \leq 0.05$ was used.

At the first stage of the experiment (September-October 2016), we introduced the PP into the educational process of female students' physical education studying in the direction of training on 38.03.02 Management. In the study, indicators for the blocks selected in AF were taken. The results indicated a low level of female students physical and functional development, their physical fitness indicators were regarded as the average for flexibility, speed, endurance, and low for power and speed-strength indicators.

The PP data were discussed with each student, and they were compared with the standard indicators of the same age female students given in the literature [2, 14] corresponding to their age. As a rule, all the departments of physical education are faced with this, and we were not an exclusion 
that in the first semester the emphasis in the educational process of physical education was focused on bringing the indicators of physical development, functional capabilities and physical fitness of the first-year students to the appropriate indicators corresponding to their age values.

At the end of the first year of study, the data on PP was collected again. The obtained results testified to the outlined positive changes in physical development, functional indicators and physical fitness of female students.

At the second stage of the experiment (September 2017 - June 2018), we in the educational process of students physical education focused on the theoretical foundations of physical education and aspects of professional and applied physical training, taking into account their profession and introduced a special course "Physical culture in the professional activity of a specialist", the content of which was compiled taking into account the variation of theoretical, methodological and practical material that allows to determine the range and nature of knowledge and skills of students in the field of physical culture and sports; mastering theoretical knowledge in this field and skills to use them competently in practice; instilling them with professional skills and abilities of physical culture means application in the further professional activity; formation of personal and physical qualities at future graduates.

During the academic year, we continued to collect data on the blocks of PP (September 2017, May 2018), followed by informing and discussing their results with students. Each student built an individual trajectory of professional development.

Analysis of the second year of study showed that the students continued to increase the performance of all selected blocks of PP.

At the final stage of the experiment (September-October 2018), we collected data on PP indicators and assessed the level of future managers physical readiness for subsequent professional activities.

\section{RESULTS AND DISCUSSION}

Monitoring of indicators on blocks of PP during the experiment are presented in Tables 1,2, 3 .

On the block "physical development": the obtained values of body length and weight, chest excursions, in the examined girls were average by the standards of the Volga Federal district of the Russian Federation [14]. With an average growth of $163.75 \pm 2.25 \mathrm{~cm}$, the students had the following data: $\mathrm{OGK}_{\mathrm{bi}}=89.78 \pm 2.62 \mathrm{~cm}, \mathrm{OGK}_{\mathrm{bo}}=83.02 \pm 2.62$ $\mathrm{cm}, \mathrm{OGK}_{\mathrm{p}}=85.59 \pm 2.52 \mathrm{~cm}$, and $\mathrm{OGK}_{\mathrm{ex}}=6.58 \pm 0.94 \mathrm{~cm}$. Low chest circumference results from the poor development of the respiratory muscles.

Wrist dynamometry for the right hand was $15.01 \pm 1.17$ $\mathrm{kg}$, for the left $-14.44 \pm 0.83 \mathrm{~kg}$. Comparing the indicators of physical development at the beginning and end of academic years, it can be noted that no significant changes in anthropometric parameters were observed $(\mathrm{P}>0.05)$.
TABLE I. INDICATORS OF PHYSICAL DEVELOPMENT OF THE SURVEYED STUDENTS DURING THE EXPERIMENT ( $\mathrm{N}=100$ PEOPLE)

\begin{tabular}{|c|c|c|c|c|c|c|c|c|c|}
\hline \multicolumn{10}{|c|}{ Indicators $(\mathrm{M} \pm \mathrm{m})$} \\
\hline \multicolumn{2}{|c|}{$\begin{array}{c}\text { Body length, } \\
\mathrm{cm}\end{array}$} & \multirow{2}{*}{$\begin{array}{l}\text { Wei } \\
\text { ght, } \\
\text { kg }\end{array}$} & \multicolumn{4}{|c|}{ Chest circumference, $\mathrm{cm}$} & \multicolumn{3}{|c|}{ Power, kg } \\
\hline $\begin{array}{l}\text { stan } \\
\text { ding }\end{array}$ & $\begin{array}{c}\text { sittin } \\
\mathrm{g}\end{array}$ & & $\begin{array}{l}\text { breat } \\
\mathrm{h} \text { in }\end{array}$ & $\begin{array}{l}\text { breat } \\
\text { h out }\end{array}$ & $\begin{array}{c}\text { paus } \\
\mathrm{e}\end{array}$ & $\begin{array}{c}\text { exc } \\
\text { ursi } \\
\text { on }\end{array}$ & $\begin{array}{c}\text { back } \\
\text { bone } \\
\text { of }\end{array}$ & $\begin{array}{l}\text { right } \\
\text { hand }\end{array}$ & $\begin{array}{l}\text { left } \\
\text { hand }\end{array}$ \\
\hline \multicolumn{10}{|c|}{ the beginning of the $2016 / 2017$ school year } \\
\hline $163,7 \pm 2$ & $85,72 \pm$ & $57,43 \pm$ & $89,40 \pm$ & $82,86 \pm$ & $85,32 \pm$ & $6,56 \pm$ & $58,56 \pm$ & $13,34 \pm$ & $13,19 \pm$ \\
\hline 25 & 4.30 & 3.14 & 2.62 & 2.62 & 2.62 & 0.94 & 6.18 & 1.89 & 1,47 \\
\hline \multicolumn{10}{|c|}{ the end of the $2016 / 2017$ school year } \\
\hline & 85,7 & 57,3 & 89,7 & 82,9 & 85,4 & 6,54 & 59,2 & 14,5 & 14,0 \\
\hline $\begin{array}{c}163,8 \pm 2 . \\
25\end{array}$ & $\begin{array}{c}4 \pm 4 . \\
30\end{array}$ & $\begin{array}{c}3 \pm 3 . \\
14\end{array}$ & $\begin{array}{c}0 \pm 2 \\
62\end{array}$ & $\begin{array}{c}4 \pm 2 \\
62\end{array}$ & $\begin{array}{c}6 \pm 2 \\
52\end{array}$ & $\begin{array}{c} \pm 0.9 \\
4\end{array}$ & $\begin{array}{c}2 \pm 4 \\
72\end{array}$ & $\begin{array}{c}6 \pm 1 \\
26\end{array}$ & $\begin{array}{c}2 \pm 0, \\
94\end{array}$ \\
\hline \multicolumn{10}{|c|}{ the beginning of the $2017 / 2018$ school year } \\
\hline & 85,7 & 57,1 & 89,8 & 83,0 & 85,5 & 6,50 & 59,4 & 14,6 & 14,1 \\
\hline $\begin{array}{c}163,8 \pm \\
2.25\end{array}$ & $\begin{array}{c}4 \pm 4 . \\
30\end{array}$ & $\begin{array}{c}6 \pm 3 . \\
14\end{array}$ & $\begin{array}{c}0 \pm 2 \\
62\end{array}$ & $\begin{array}{c}4 \pm 2 \\
62\end{array}$ & $\begin{array}{c}8 \pm 2 \\
52\end{array}$ & $\begin{array}{c} \pm 0.9 \\
4\end{array}$ & $\begin{array}{c}0 \pm 4 \\
72\end{array}$ & $\begin{array}{c}6 \pm 1 \\
26\end{array}$ & $\begin{array}{c}0 \pm 0, \\
94\end{array}$ \\
\hline \multicolumn{10}{|c|}{ the end of the $2017 / 2018$ school year } \\
\hline 163, & 85,7 & 56,9 & 89,8 & 83,1 & 85,7 & 6,52 & 59,8 & 15,6 & 14,9 \\
\hline $\begin{array}{c}8 \pm 2 . \\
25\end{array}$ & $\begin{array}{c}5 \pm 4 . \\
30\end{array}$ & $\begin{array}{c}5 \pm 3 \\
14\end{array}$ & $\begin{array}{c}2 \pm 2 \\
62\end{array}$ & $\begin{array}{c}6 \pm 2 \\
62\end{array}$ & $\begin{array}{c}0 \pm 2 \\
52\end{array}$ & $\begin{array}{c} \pm 0.9 \\
4\end{array}$ & $\begin{array}{c}2 \pm 4 \\
30\end{array}$ & $\begin{array}{c}0 \pm 1 \\
26\end{array}$ & $\begin{array}{c}8 \pm 0 \\
52\end{array}$ \\
\hline \multicolumn{10}{|c|}{ the beginning of the $2018 / 2019$ school year } \\
\hline 163, & 85,7 & 57,1 & 90,0 & 83,1 & 85,9 & 6,80 & 60,0 & 16,9 & 15,9 \\
\hline $\begin{array}{c}8 \pm 2 . \\
25\end{array}$ & $\begin{array}{c}4 \pm 4 . \\
30\end{array}$ & $\begin{array}{c}6 \pm 3 \\
14\end{array}$ & $\begin{array}{c}2 \pm 2 \\
62\end{array}$ & $\begin{array}{c}4 \pm 2 \\
62\end{array}$ & $\begin{array}{c}2 \pm 2 \\
52\end{array}$ & $\begin{array}{c} \pm 0.9 \\
4\end{array}$ & $\begin{array}{c}0 \pm 3 \\
88\end{array}$ & $\begin{array}{c}2 \pm 0 . \\
21\end{array}$ & $\begin{array}{c}4 \pm 0, \\
31\end{array}$ \\
\hline
\end{tabular}

TABLE II. INDICATORS OF PHYSICAL ABILITIES OF GIRLS DURING THE EXPERIMENT ( $\mathrm{N}=100$ PEOPLE)

\begin{tabular}{|c|c|c|c|c|}
\hline \multicolumn{5}{|c|}{ Indicators $(\mathrm{M} \pm \mathrm{m})$} \\
\hline 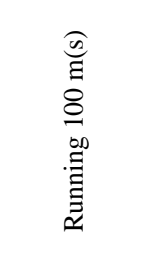 & 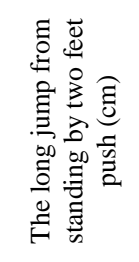 & 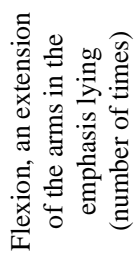 & 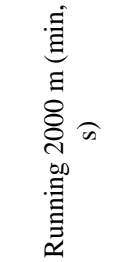 & 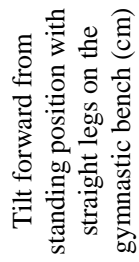 \\
\hline \multicolumn{5}{|c|}{ the beginning of the $2016 / 2017$ school year } \\
\hline $17,49 \pm 0,62$ & $170,0 \pm 7,55$ & $9,98 \pm 1,26$ & $12,49 \pm 1,14$ & $10,1 \pm 1,41$ \\
\hline \multicolumn{5}{|c|}{ the end of the $2016 / 2017$ school year } \\
\hline $17,44 \pm 0,60$ & $170,6 \pm 6,92$ & $11,00 \pm 1,26$ & $12,43 \pm 0,99$ & $12,63 \pm 2,04$ \\
\hline \multicolumn{5}{|c|}{ the beginning of the $2017 / 2018$ school year } \\
\hline $17,47 \pm 0,60$ & $170,7 \pm 6,92$ & $10,96 \pm 1,26$ & $12,39 \pm 0,84$ & $12,62 \pm 1,97$ \\
\hline \multicolumn{5}{|c|}{ the end of the $2017 / 2018$ school year } \\
\hline $17,16 \pm 0,32$ & $170,9 \pm 6,71$ & $12,12 \pm 0,84$ & $12,10 \pm 0,42$ & $13,15 \pm 1,55$ \\
\hline \multicolumn{5}{|c|}{ the beginning of the $2018 / 2019$ school year } \\
\hline $17,19 \pm 0,28$ & $171,6 \pm 6,50$ & $13,00 \pm 0,63$ & $12,03 \pm 0,41$ & $13,59 \pm 1,34$ \\
\hline
\end{tabular}

On the block of the cardiorespiratory system functional indicators: it was found that the heart rate was changed slightly and tended to decrease from the beginning to the end of each semester, the difference between these indicators was insignificant $(\mathrm{P}>0.05)$ and lay in the range of $71.0 \pm 1.91-79.0 \pm 1.99$ beats $/ \mathrm{min}$. Systolic blood pressure and diastolic blood pressure values also decreased during the study period, respectively, from $114.2 \pm 2.37$ to $106.1 \pm 1.50$ $\mathrm{mm} \mathrm{Hg}$. art and from $86,6 \pm 2,37$ to $68,7 \pm 2,00 \mathrm{~mm} \mathrm{Hg}$. art., and, at the beginning of the fifth semester, Systolic blood pressure was significantly higher than that value in the first semester. The data of Systolic blood pressure and diastolic blood pressure was not reduced significantly and were within the normal age-related values. Medium pressure had a similar downward trend $(45.7 \pm 2.43$ at the beginning of 
the 1st course and $37.9 \pm 1.31 \mathrm{~mm} \mathrm{Hg}$ at the beginning of the 3rd course) $(\mathrm{P}>0,05)$. Lung capacity at students was defined at the level of $3.68 \pm 0.621$. Low chest circumference and lung capacity are due to poor development of the respiratory muscles. However, the Lung capacity increased from year to year without a significant difference in semesters $(3.5 \pm 0.431$ at the beginning of the 1st course versus $3.9 \pm 1.21 \mathrm{l}$ at the beginning of the 3rd course of study). According to the results of our research, this indicates an increase in the physical development of the examined organism [2], due to the introduction of changes in the training sessions on physical education. Samples of Shtange and Genchiwere rated as "good." 54.34 \pm 2.89 and $29.9 \pm 1.76$ s, respectively.

TABLE III. FUNCTIONAL INDICATORS OF THE CARDIORESPIRATORY SYSTEM OF GIRLS DURING THE EXPERIMENT PERIOD ( $\mathrm{N}=100$ PEOPLE)

\begin{tabular}{|c|c|c|c|c|c|c|}
\hline \multicolumn{7}{|c|}{ Indicators $(\mathrm{M} \pm \mathrm{m})$} \\
\hline \multirow[b]{2}{*}{$\begin{array}{c}\text { Heart } \\
\text { rate,bp } \\
\mathrm{m}\end{array}$} & \multicolumn{3}{|c|}{$\begin{array}{l}\text { Arterial tension, } \\
\mathrm{mm} \mathrm{Hg} \text {. art. }\end{array}$} & \multirow[b]{2}{*}{$\begin{array}{c}\text { Lung } \\
\text { capacit } \\
\mathrm{y}, 1\end{array}$} & \multicolumn{2}{|c|}{ Samples, s } \\
\hline & $\begin{array}{c}\text { Systoli } \\
\text { c } \\
\text { blood } \\
\text { pressu } \\
\text { re }\end{array}$ & $\begin{array}{l}\text { Diastol } \\
\text { ic } \\
\text { blood } \\
\text { pressur } \\
\text { e }\end{array}$ & $\begin{array}{c}\text { Mediu } \\
\mathrm{m} \\
\text { pressur } \\
\mathrm{e}\end{array}$ & & Shtange & enchi \\
\hline \multicolumn{7}{|c|}{ the beginning of the $2016-2017$ school year } \\
\hline $\begin{array}{c}77,4 \pm 3 \\
85\end{array}$ & $\begin{array}{c}114,2 \pm \\
2,37\end{array}$ & $\begin{array}{c}86,6 \pm \\
2,37\end{array}$ & $\begin{array}{c}45,7 \pm \\
2,43\end{array}$ & $\begin{array}{c}3,5 \pm 0,4 \\
3\end{array}$ & $\begin{array}{c}46,0 \pm 2 \\
25\end{array}$ & $\begin{array}{c}29,6 \pm 1 \\
78\end{array}$ \\
\hline \multicolumn{7}{|c|}{ the end of the 2016-2017 school year } \\
\hline $\begin{array}{c}76,1 \pm 1 \\
54\end{array}$ & $\begin{array}{c}111,7 \pm \\
2,01\end{array}$ & $\begin{array}{c}66,2 \pm \\
1,95\end{array}$ & $\begin{array}{c}45,4 \pm \\
1,48\end{array}$ & $\begin{array}{c}3,7 \pm 0,4 \\
3\end{array}$ & $\begin{array}{c}87,7 \pm 5 \\
46\end{array}$ & $\begin{array}{c}31,1 \pm 1 \\
72\end{array}$ \\
\hline \multicolumn{7}{|c|}{ the beginning of the $2017-2018$ school year } \\
\hline $\begin{array}{c}79,0 \pm 1 \\
99\end{array}$ & $\begin{array}{c}107,1 \pm \\
2,10\end{array}$ & $\begin{array}{c}69,1 \pm \\
3,20\end{array}$ & $\begin{array}{c}37,5 \pm \\
1,81\end{array}$ & $\begin{array}{c}3,5 \pm 0,7 \\
2\end{array}$ & $\begin{array}{c}46,0 \pm 2 \\
25\end{array}$ & $\begin{array}{c}29,6 \pm 1 \\
78\end{array}$ \\
\hline \multicolumn{7}{|c|}{ the end of the 2017-2018 school year } \\
\hline $\begin{array}{l}76,0 \pm 0 \\
90\end{array}$ & $\begin{array}{c}103,7 \pm \\
1,70\end{array}$ & $\begin{array}{c}62,96 \pm \\
1,80 \\
\end{array}$ & $\begin{array}{c}33,4 \pm \\
1,92 \\
\end{array}$ & $\begin{array}{c}3,8 \pm 0,3 \\
5\end{array}$ & $\begin{array}{c}46,0 \pm 2 \\
25\end{array}$ & $\begin{array}{c}29,6 \pm 1 \\
78\end{array}$ \\
\hline \multicolumn{7}{|c|}{ the beginning of the 2018-2019 school year } \\
\hline $\begin{array}{c}71,0 \pm 1 \\
90\end{array}$ & $\begin{array}{c}106,1 \pm \\
1,50\end{array}$ & $\begin{array}{l}68,7 \pm \\
2,00 *\end{array}$ & $\begin{array}{c}37,9 \pm \\
1,31\end{array}$ & $\begin{array}{c}3,9 \pm 1,2 \\
1\end{array}$ & $\begin{array}{c}46,0 \pm 2 \\
25\end{array}$ & $\begin{array}{c}29,6 \pm 1 \\
78\end{array}$ \\
\hline
\end{tabular}

The decrease in the studied parameters of the cardiovascular system, throughout the experiment, is explained by the economization of its activity during adaptation to physical loads.

\section{DISCUSSION}

Consideration of the physical readiness block allowed to establish that at the beginning of experiment physical abilities of girls was average on speed, endurance, and indicators of flexibility; low - on power and speed-power. During the entire period of the experiment, there was an increase in quantitative indicators of all students physical abilities, but the difference between these indicators was insignificant $(\mathrm{P}>0.05)$ and lay in the range of speed $17,49 \pm 0,62-17,19 \pm 0,28 \mathrm{~s} ; \quad$ speed-power - 170,04 $\pm 7,55-$ $171,55 \pm 6,50 \mathrm{~cm}$; power - 9,98 $\pm 1,26-13,00 \pm 0,63$ (times); endurance $-12,49 \pm 1,14-12,03 \pm 0,41 \mathrm{~min} ., \mathrm{s}$ and flexibility $10,1 \pm 1,41-13,59 \pm 1,34 \mathrm{~cm}$.

The increase in indicators for all blocks of PP is explained by the fact that every time the data were collected and processed, they were informed and discussed with the surveyed people, after which, with each of them, an individual trajectory of professional development was built. The analysis of the obtained results indicated that the experiment made it possible to improve the indicators of physical development, functional capabilities and physical fitness of the students, thereby improving the level of future graduates physical readiness for upcoming professional activities.

\section{CONCLUSION}

Thus, we believe that the experiment proved the effectiveness of physical training use in the educational process of students physical education in the direction of training 38.03.02 Management. It was one of the effective means in the formation in future managers of the proper level of physical readiness to perform their professional duties in the future. Monitoring of PP indicators throughout the period of study of disciplines "Physical culture and sport" and "Physical culture and sport (elective discipline)" allows making timely adjustments to the content and methodological support of the physical education teaching process, for effective training of managerial personnel.

The theoretical significance of the study is that it complements the theory and methodology of vocational education with ideas about the use of PP in the course of professional and applied physical training for the formation in future graduates of the necessary physical readiness level for subsequent professional activity.

The practical significance of the study is the application of this development in the process of students' physical education. It will allow them to achieve the necessary level of physical readiness in relation to the profession.

\section{References}

[1] Aithal, P.S., Aithal, S. An innovative education model to realize ideal education system. International Journal of scientific research and management (IJSRM). 2015, vol. 3, 3, pp. 2464-2469.

[2] Altynova, N.V. Analysis of the characteristics of the respiratory system of younger students in conditions of selenium deficiency. In the collection: Research results Collection of articles of the International Scientific and Practical Conference. Executive editor Sukiasyan Asatur Albertovich. 2015, pp. 29-32.

[3] Badwan, J.J. et al. Adopting technology for customer relationship management in higher educational institutions //International Journal of Engineering and Information Systems (IJEAIS). 2017, vol. 1, 1, pp. 20-28.

[4] Chernikh, Z.N., Borisenko T.M. The influence of physical culture and sports activities on the formation of professional readiness of students of a pedagogical university. Bulletin of ShGPU. 2017, 1(33), URL: https://cyberleninka.ru/article/n/vliyanie-fizkulturno-sportivnoydeyatelnosti-na-formirovanie-professionalnoy-gotovnosti-studentovpedagogicheskogo-vuza.

[5] Chin, M., Edginton, K. Physical Education and Health: Global Perspectives and Best Practice. Sagamore Publishing LLG. 2014. URL:

http://www.sagamorepub.com/files/lookinside/432/peandhealthglobal perspectives-

[6] Dvornikova, A. S. Physical preparedness of students as an element of the professional culture of the future specialist. Scientific community of students of the XXI century. Humanities: a collection of articles on the mat. LVIII]. stud. science.-pract. conf. 2017, 10(58). - Electron. URL: https://sibac.info/archive/guman/10 (58).pdf.

[7] Dyachenko, M.I., Kandybovich M.I. Psychology of higher education: 
Humanities and Natural Sciences. 2018, 2. URL: https://cyberleninka.ru/article/n/usloviya-napravlennogofizicheskogo-vospitaniya-i-formirovaniya-navykov-u-studentov-nazanyatiyah-po-fizicheskoy-kulture-v-neprofilnyh.

[24] Titov S.V., Kuznetsova Z.M. Rise of physical fitness level in special student's medical groups by means of athletic gymnastics. Pedagogico-psychological and medico-biological problems of physical culture and sport. 2009, vol. 4(4), pp. 120-125. URL: http://www.vak.webtm.ru/images/vipuski/4-1/4.pdf
[9] Kamenskaya, V.V., Penkova O.V. The quality of training of graduates in the assessment of employers: competence approach. Modern high technologies. 2016, 3-2, pp. 350-354. URL: http://toptechnologies.ru/ru/article/view?id=35749.

[10] Kern, J. S. modern Requirements of employers for graduates of the University: competence approach. Science and education ONLINE (Science, practice, modernity). 2017. Electron. URL: https://student.eee-science.ru/listing/trebovaniya-sovremennyhrabotodatelej-k-vypusknikam-vuza-kompetentnostnyj-podhod/.

[11] Kohl, III, H., Cook, H. Education the Student Body: Taking Physical Activity and Physical Education to School. National Academies Press (US). 2013. Electron. URL: http://csmp.ucop.edu/resources/materials/IOM_recomendations.pdf

[12] Lavay, B., French, R., Henderson, H. Positive Behavior Management in Physical Activity Settings, 3E. Human Kinetics, 2015.

[13] Meermanova, I.B., Koygeldinova S.S., Ibraev S.A. The health of students in Higher Education. international journal of applied and fundamental research. 2017, 2-2, pp. 193-197. URL: http://appliedresearch.ru/ru/article/view?id=11244.

[14] Mikhailova, S.V., Kuzmichev Yu.G., Krylov V.N. et. Al. Monitoring of physical development of students of Nizhny Novgorod region. Modern scientific research and innovation. 2016, 9. URL: http://web.snauka.ru/issues/2016/09/72003.

[15] Reznik, V.V. Readiness of students of economic specialties in professional activity: essence and structure. URL: http://www.infolibrary.com.ua/libs/stattya/6102-gotovnist-studentiv-ekonomichnihspetsialnostej-do-profesijnoyi-dijalnosti-sutnist-ta-struktura.html.

[16] Saifutdinova, G.B. Pedagogical conditions of formation at future power engineers of General cultural competences in the course of studying of disciplines of the socio-humanistic direction. Philological Sciences. Theory and practice. Tambov: Diploma. 2016, 11 (65), II, pp. 197-200. URL: https://cyberleninka.ru/article/n/usloviyanapravlennogo-fizicheskogo-vospitaniya-i-formirovaniya-navykov-ustudentov-na-zanyatiyah-po-fizicheskoy-kulture-v-neprofilnyh.

[17] Schneider, M. G., Pyanzina N.N., Kolesnikova O.B. Psychophysical readiness for professional activity of students of economic specialties and features of its formation in the process of physical education. In the collection: Actual problems of physical culture and sports in modern socio-economic conditions Materials of the International scientific-practical conference dedicated to the 100th anniversary of the National University of Uzbekistan named after MirzoUlugbek. 2018, pp. 175-181.

[18] Talantseva, V.K., Volkova I.T., Surikov A.A. Ways to improve the process of formation of the psychophysical readiness of bachelors of economics to professional activity. Problems of modern pedagogical education. 2017, 57-8, pp. 247-257.

[19] The list of popular professions in 2020-2025. What professions will be in demand in 10 years. URL: http://fb.ru/article/349948/spisokvostrebovannyih-professiy-v---godah-kakie-professii-budutvostrebovanyi-cherez-let ahhh!

[20] The top 20 occupations in demand in 2019. Journal ProfiKomment. URL: https://proficomment.ru/20-perspektivnyx-professij-v-2016godu/

[21] Trifonova, T. V. Physical preparedness of students as an element of the professional culture of the future specialist. Student scientific forum: materials of the IX International student scientific conference. 2017, URL: https://scienceforum.ru/2017/article/2017040779<a〉.

[22] Zavydivska O. I. et al. The paradigm of health maintenance at higher education institutions as an important component of human development in terms of modernity. Journal of Physical Education and Sport. 2017, vol. 17, pp. 60.

[23] Zhukova, I. V. Conditions of the directed physical education and formation of skills at students at occupations on physical culture in non-core higher education institutions. International journal of 